\title{
Reinforced Concrete Strength at Slab and Column Intersection
}

(Date received: 15.2.2017/Date accepted: 13.2.2018)

\section{Ir. Siao Wen Bin}

\section{ABSTRACT}

This paper proposes a method modified from that as first suggested by Siaol to determine the effect on column strength taking into consideration the effect of confinement by the surrounding slab. Previous test results ${ }^{2-4}$ obtained by others (37 test specimens in total) have been used to justify the proposed method. Results show reasonable agreement between actual and predicted values.

Keywords: Confined Concrete, Column Strength, Floor Slab

\subsection{INTRODUCTION}

Present day reinforced concrete column construction involves high strength concrete. But floor slab systems are of lower concrete strength. The $\mathrm{ACI}^{5}$ code lays down guidelines for determining concrete strength of column at the slab/column junction under such circumstances but this does not take into account the effect of slab reinforcement and its contribution to confinement stress on the column concrete. By increasing the amount of slab reinforcement, column strength in the slab can be raised and hence no special precaution or consideration as recommended by the code may be required when column strength exceeds 1.4 times the strength of the slab system if sufficient confinement reinforcement is provided in slab.

\section{RESEARCH SIGNIFICANCE}

A rational method of determining column strength at its intersection with the floor system would be highly desirable to designers when encountering concrete with different strengths for the column and slab systems as column strength tends to be higher for obvious reasons. This could mean obviating the need to use concrete of higher strength for the floor slab in and around the column.

\section{THEORY}

As first suggested by $\mathrm{Siao}^{1}$ the concrete at the column/ slab intersection is subjected to triaxial stresses and due to confinement stresses generated from the slab reinforcement the concrete failure stress is raised by an amount equal to the confinement stress multiplied by a factor k1. Using a modified equation as proposed by $\mathrm{Siao}^{1}$ the apparent floor concrete strength $f_{c p}^{\prime}$ is predicted by:

$$
0.85 f_{c p}^{\prime}=0.85 f_{c s}^{\prime}+\mathrm{k}_{1} \mathrm{f}_{1}
$$

where

$f_{c s}^{\prime}=$ cylinder strength of floor concrete,

$\mathrm{f}_{1} \quad=$ confinement stress

$\mathrm{k}_{1}$ is proposed ${ }^{1}$ to be 5
The specimens (see Figures 1-3) which were tested by others ${ }^{2-4}$ have been used to determine the validity of the Eq.(1). The effective or actual floor concrete strength $f_{c e}^{\prime}$ is computed using the following equation :

$$
\mathrm{P}_{\mathrm{u}}=\mathrm{A}_{s} \mathrm{f}_{\mathrm{y}}+\mathrm{A}_{\mathrm{n}} 0.85 f_{c e}^{\prime}
$$

where

$\mathrm{P}_{\mathrm{u}}=$ actual failure load,

$\mathrm{A}_{\mathrm{s}}=$ steel reinforcement area,

$f_{y}=$ yield stress of steel,

$\mathrm{A}_{\mathrm{n}}=$ net area of concrete.

\section{DETERMINATION OF CONFINEMENT PRESSURE}

Figures 4-5 show the crack pattern in the slabs tested by others ${ }^{2-4}$ to failure. These will affect the way in which slab reinforcement is taken into consideration in determining confinement pressure at the column/slab junction.

\section{BIANCHINI ET AL'S SPECIMENS ${ }^{2}$}

Figure 4 shows how confinement pressure $f_{1}$ is generated in the slabs tested by Bianchini et $\mathrm{al}^{2}$. By considering equilibrium of forces acting on portion of the slab ' $\mathrm{e} \mathrm{f} \mathrm{g} \mathrm{h} \mathrm{I} \mathrm{j}$ ' the slab reinforcements contributing to confinement pressure on one face of column are slab bars 'a', 'b', 'c' and 'd'. However it is observed that the lengths of these bars are insufficient to develop the full yield strength of the steel. Full development length in tension is given by the equation ${ }^{5}$.

Where

$$
l_{d}=\frac{f_{y}}{25 \sqrt{f_{c}^{\prime}}} d_{b}
$$

$l_{d}=$ development length, in.

$d_{b}=$ bar diameter, in.

$f_{c}^{\prime}=$ cylinder strength of floor concrete, psi.

$\mathrm{f}_{\mathrm{y}}=$ yield stress of steel, psi.

It is also observed that longitudinal splitting cracks occurred in the slabs where the reinforcements are placed due possibly to insufficient anchorage length for full development of yield stress. Sample calculations are included in the appendix to show how confinement pressure is obtained in such a case. 


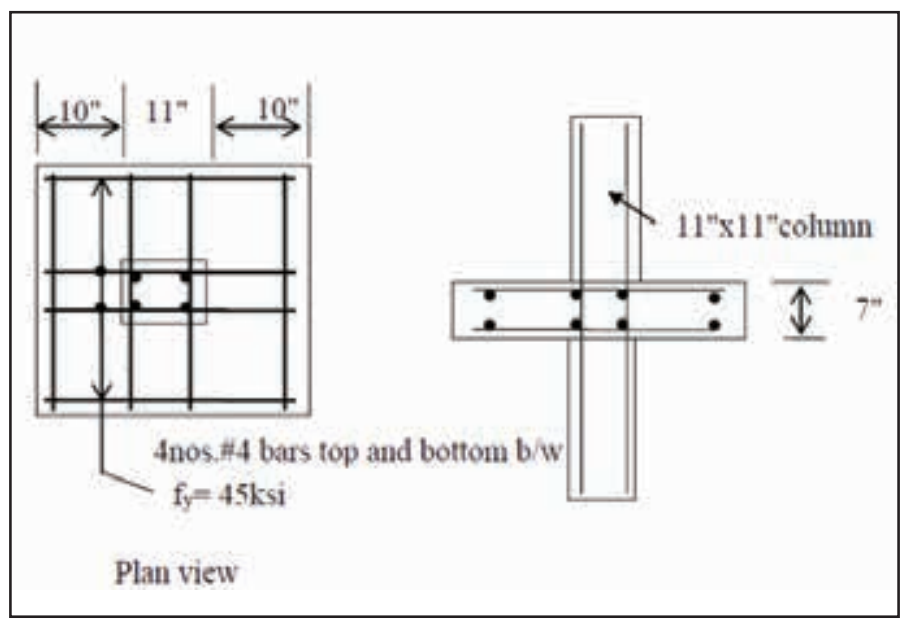

Figure 1: Bianchini's ${ }^{2}$ slab specimen

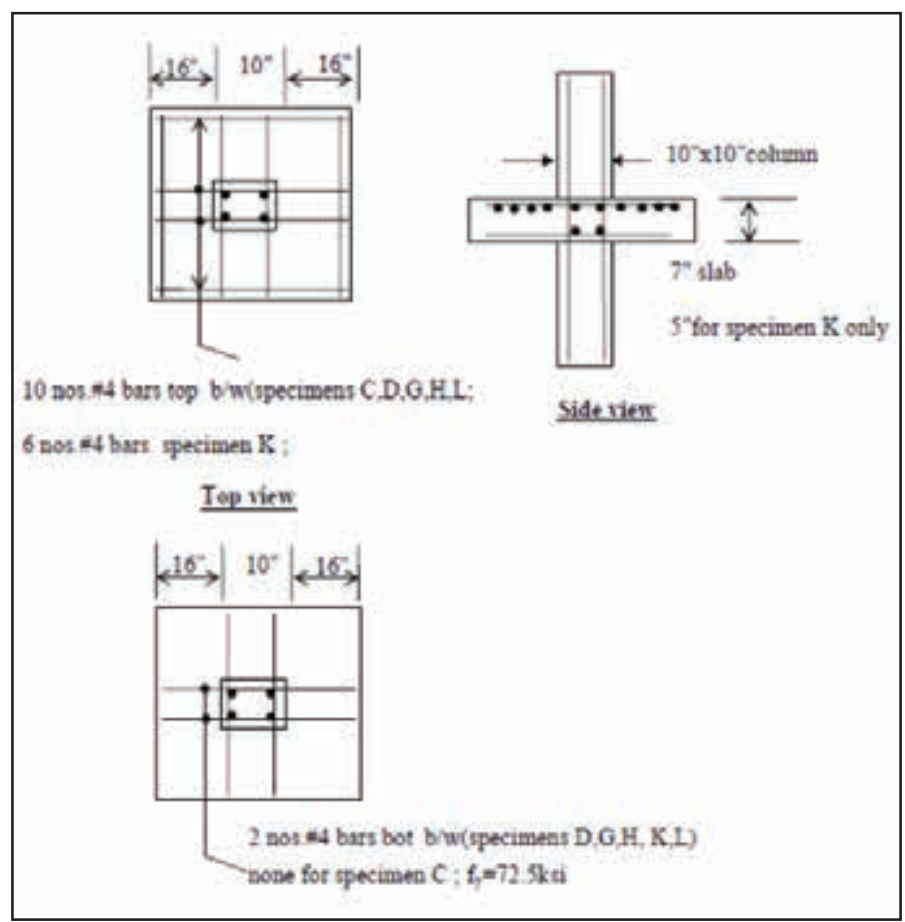

Figure 2: Gamble et al's ${ }^{4}$ specimens

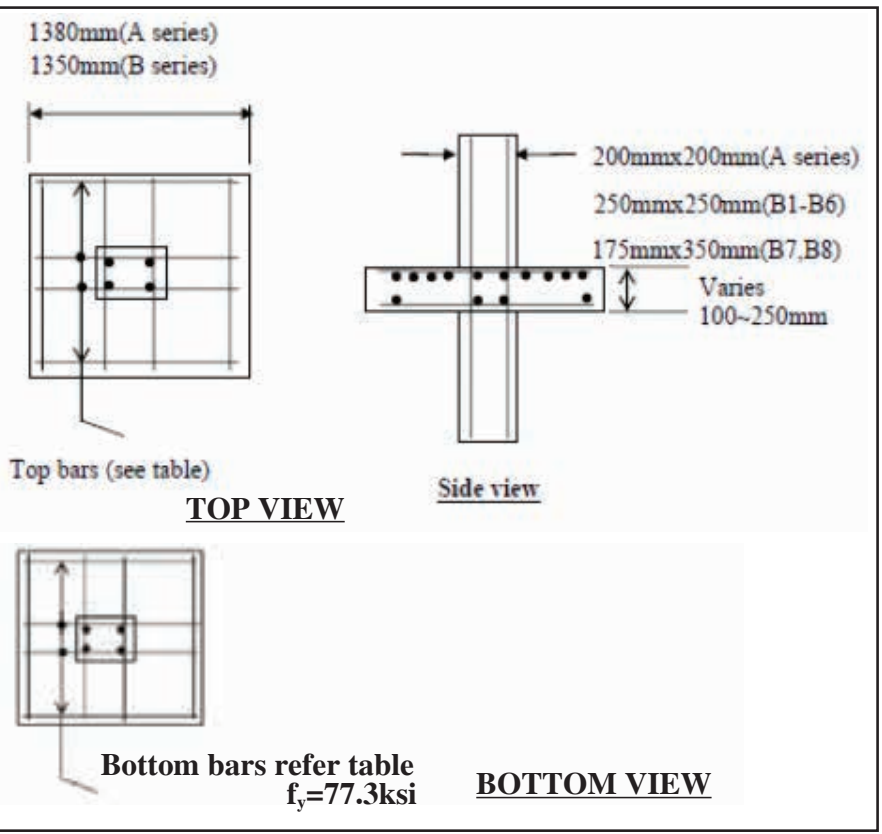

Figure 3: Ospina's specimens

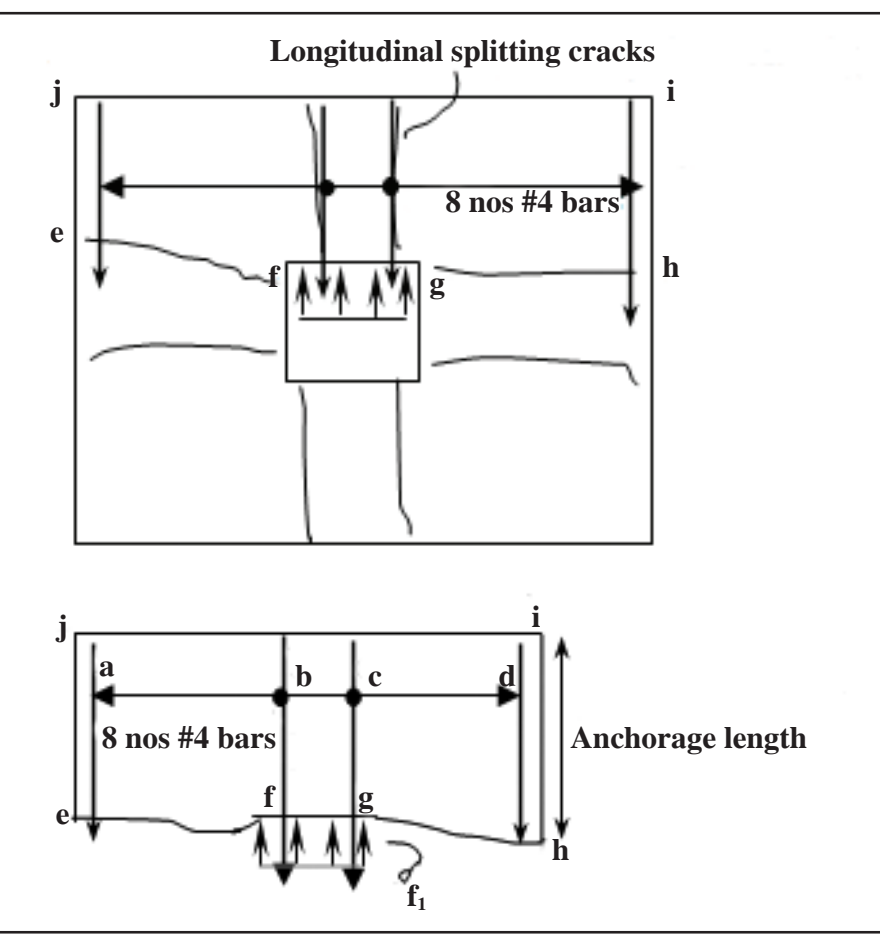

Figure 4: Crack pattern in Bianchini's slab ${ }^{2}$ and bars contributing to confinement stress

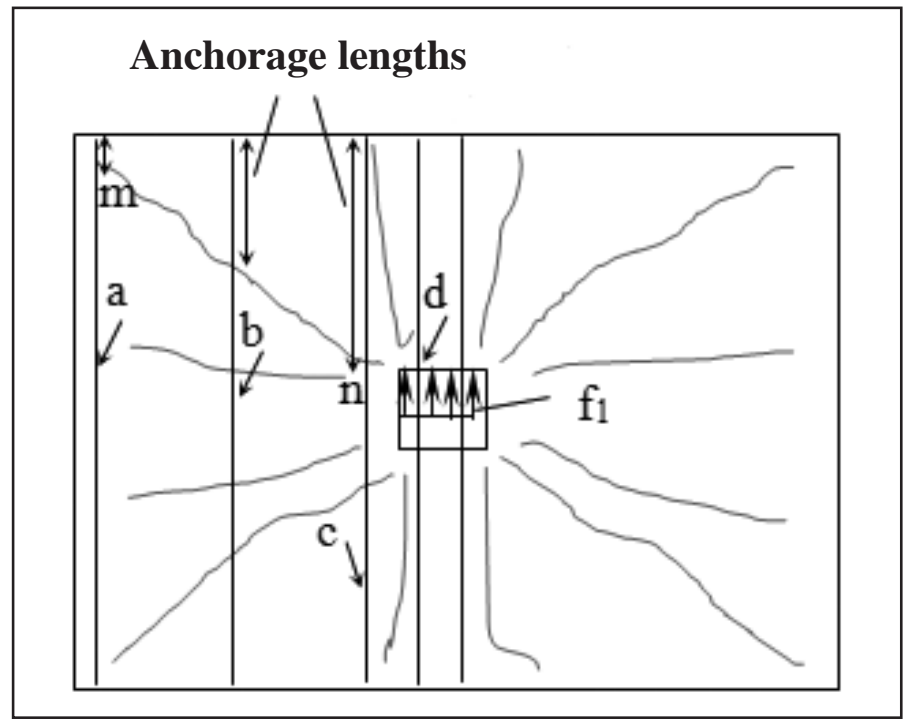

Figure 5: Crack pattern in Gamble et al and Ospina et al's slab ${ }^{3,4}$ and effective anchorage length of slab reinforcements

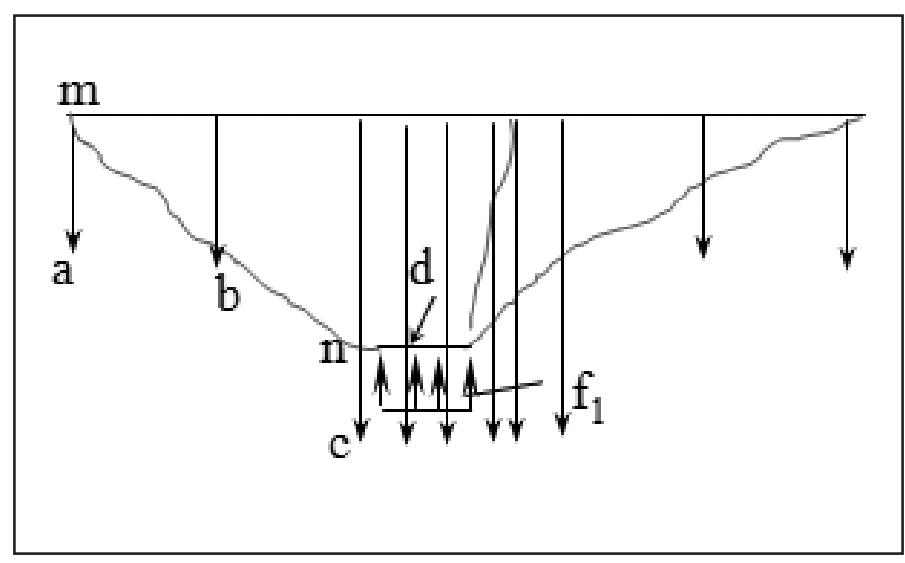

Figure 6: Slab reinforcement bars ${ }^{3,4}$ contributing to confinement stress 


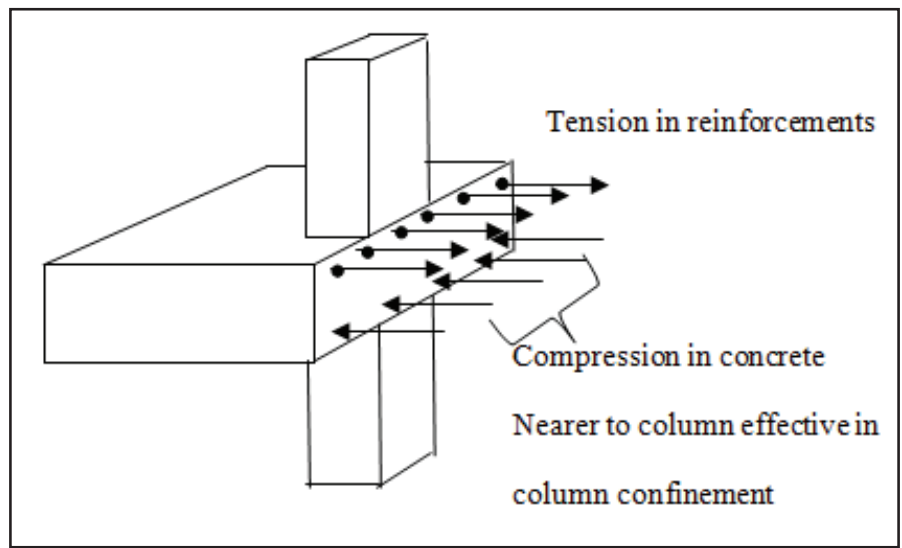

Figure 7: Forces acting across face of column due to moment in slab ${ }^{3}$

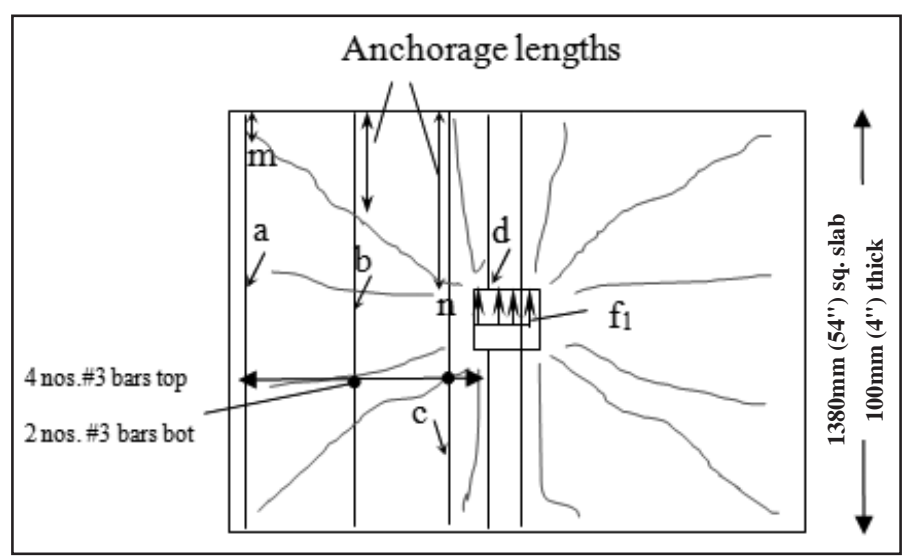

Figure 8: Crack pattern in slab specimen A1- $A^{3}$ and effective anchorage length of slab reinforcements

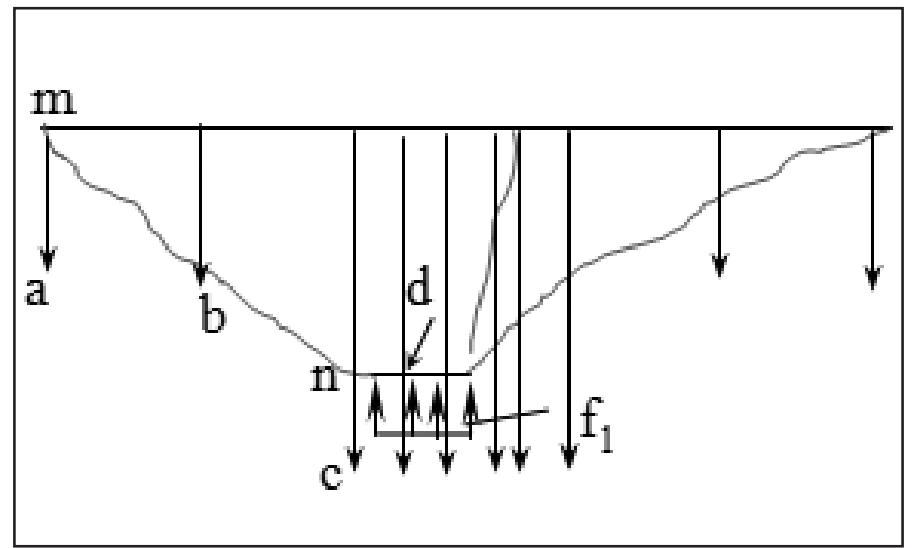

Figure 9: Slab reinforcement bars ${ }^{3}$ contributing to confinement stress

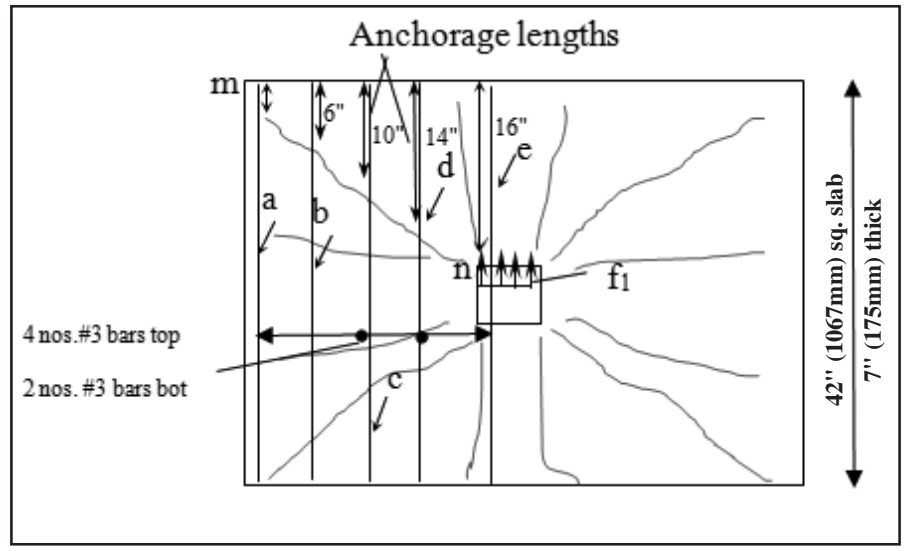

Figure 10: Crack pattern in slab specimen $C^{4}$ and effective anchorage length of slab reinforcements

$\mathrm{m}$

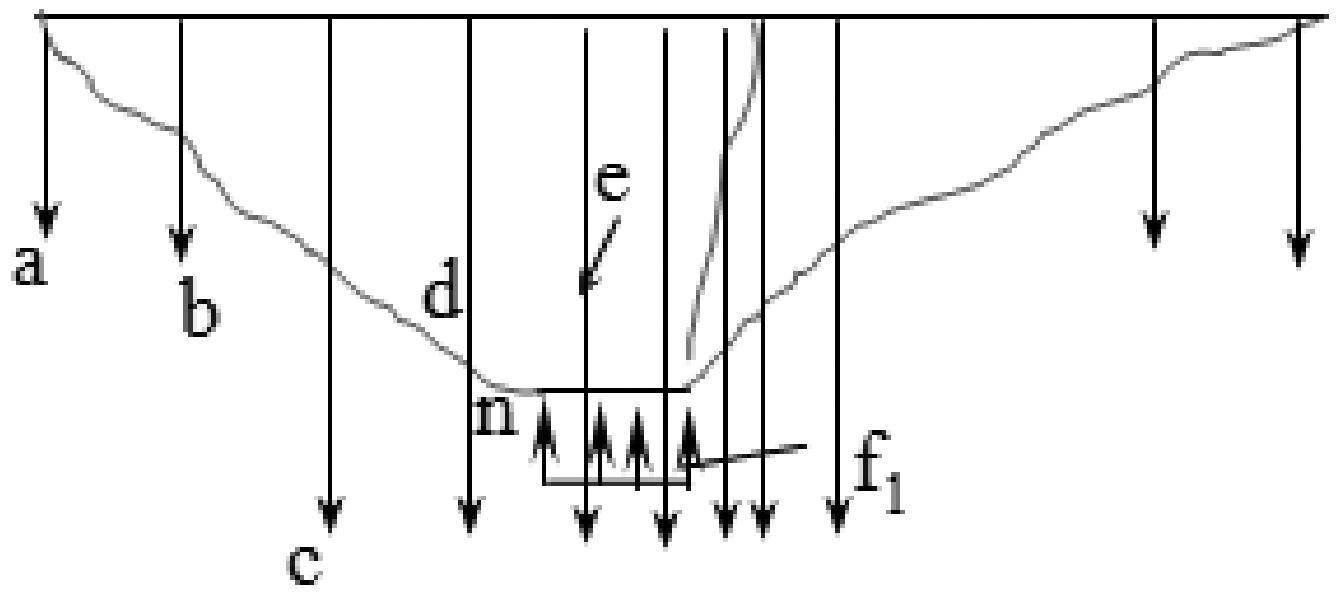

Figure 11: Slab reinforcement bars ${ }^{4}$ contributing to confinement stress 


\section{OSPINA ET AL ${ }^{3}$ AND GAMBLE ET AL ${ }^{4}$ 'S SPECIMENS}

Figure 5 shows the crack pattern in test specimens by Ospina et $\mathrm{al}^{3}$ and Gamble et $\mathrm{al}^{4}$. These were different from Bianchini et al 's specimens ${ }^{2}$. The former showed diagonal cracks $m \mathrm{n}$ extending from corner of column to corner of slab. Figure 6 shows the free body diagram of forces acting on one quarter of the slab. Slab bar ' $a$ ' can be ignored as anchorage length is minimal. For bars 'b' , 'c' and 'd' their anchorage lengths need to be compared against that from Eqn.(3) to determine their effectiveness which could be less than full. Also to be noted is that both top and bottom bars are to be considered even if pressure is not uniform as number of top and bottom slab bars were not the same. This could be attributed to the fact that depth of slab to column width ratio is low less than or about unity. For Ospina et al's slabs ${ }^{3}$ majority of specimens had loads applied onto the slab to induce moments in slabs at column face so that slab reinforcements were stressed to a certain percentage of or full yield strain. In such cases effectiveness of slab reinforcement in generating confinement pressure is reduced proportionately. However due to moments applied compression forces were induced at bottom of the slab as shown in Figure 7. These compression forces could still contribute to restraining forces but their effectiveness was less as only that near the column could reasonably be considered to be effective. Their effectiveness is assumed to be half (see sample calculations for specimen $\mathrm{A} 1-\mathrm{B}^{3}$ ).

\section{COMPARISON OF PREDICTIONS AND EXPERIMENTAL RESULTS}

The comparison of the predictions using the method proposed in this paper and the experimental results from the testing in the literature ${ }^{2-4}$ is shown in Table 1 . It shows that the predictions are fairly accurate. Results from three different testing programs ${ }^{2-4}$ show averages of close to 1 and standard deviations of $10 \%$.

Table 1: Test VS Predicted Slab Concrete Strength

\begin{tabular}{|c|c|c|c|c|c|c|c|c|c|}
\hline & \multirow[b]{2}{*}{ Specimen $\neq$} & \multirow{2}{*}{$\begin{array}{c}f_{c s}^{\prime} \\
\mathrm{N} / \mathrm{mm}^{2} \\
(\mathrm{psi})\end{array}$} & \multirow{2}{*}{$\underset{\substack{\mathrm{N} / \mathrm{mm}^{2} \\
(\mathrm{psi})}}{f^{\prime}}$} & \multirow[b]{2}{*}{$\frac{f_{c c}^{\prime}}{f_{c s}^{\prime}}$} & \multicolumn{2}{|c|}{ Test } & \multicolumn{2}{|c|}{ Analysis } & \multirow[b]{2}{*}{$\frac{f_{c e}^{\prime}}{f_{c p}^{\prime}}$} \\
\hline & & & & & $\begin{array}{l}\mathrm{P}_{\mathrm{u}} \mathrm{kN} \\
\text { (kips) }\end{array}$ & $\begin{array}{c}f_{c e}^{\prime} \\
\mathrm{N} / \mathrm{mm}^{2} \\
(\mathrm{psi})\end{array}$ & $\begin{array}{c}f_{1} \\
\mathrm{~N} / \mathrm{mm}^{2} \\
\text { (psi) }\end{array}$ & $\begin{array}{c}f_{c p}^{\prime} \\
\mathrm{N} / \mathrm{mm}^{2} \\
(\mathrm{psi})\end{array}$ & \\
\hline 1 & S9013.0 & $\begin{array}{c}17.1 \\
(2480)\end{array}$ & $\begin{array}{c}51 \\
(7400)\end{array}$ & 2.98 & $\begin{array}{l}3115 \\
(700)\end{array}$ & $\begin{array}{c}42.1 \\
(6110)\end{array}$ & 508 & $\begin{array}{c}37.7 \\
(5470)\end{array}$ & 1.12 \\
\hline 2 & S7513.0 & $\begin{array}{c}22.2 \\
(3220)\end{array}$ & $\begin{array}{c}51.3 \\
(7440)\end{array}$ & 2.31 & $\begin{array}{l}3289 \\
(739)\end{array}$ & $\begin{array}{c}45.2 \\
(6550)\end{array}$ & 579 & $\begin{array}{c}45.7 \\
(6625)\end{array}$ & 0.99 \\
\hline 3 & S7513.0 & $\begin{array}{c}15.9 \\
(2300)\end{array}$ & $\begin{array}{c}43.2 \\
(6260)\end{array}$ & 2.72 & $\begin{array}{l}2893 \\
(650)\end{array}$ & $\begin{array}{c}38.8 \\
(5630)\end{array}$ & 489 & $\begin{array}{c}35.7 \\
(5178)\end{array}$ & 1.09 \\
\hline 4 & S6013.0 & $\begin{array}{c}14.3 \\
(2080)\end{array}$ & $\begin{array}{c}45.3 \\
(6570)\end{array}$ & 3.17 & $\begin{array}{l}3071 \\
(690)\end{array}$ & $\begin{array}{c}41.7 \\
(6050)\end{array}$ & 465 & $\begin{array}{c}33.2 \\
(4813)\end{array}$ & 1.26 \\
\hline 5 & S60I2.0 & $\begin{array}{c}23.7 \\
(3430)\end{array}$ & $\begin{array}{c}45.7 \\
(6620)\end{array}$ & 1.93 & $\begin{array}{l}3115 \\
(700)\end{array}$ & $\begin{array}{c}42.3 \\
(6140)\end{array}$ & 598 & $\begin{array}{c}47.9 \\
(6946)\end{array}$ & $0.93^{\dagger}$ \\
\hline 6 & S5012.0 & $\begin{array}{c}21.3 \\
(3090)\end{array}$ & $\begin{array}{c}40.6 \\
(5890)\end{array}$ & 1.91 & $\begin{array}{l}2581 \\
(580)\end{array}$ & $\begin{array}{c}34.1 \\
(4940)\end{array}$ & 566 & $\begin{array}{c}44.3 \\
(6422)\end{array}$ & $0.84 \dagger$ \\
\hline 7 & S5012.0 & $\begin{array}{c}15.2 \\
(2210)\end{array}$ & $\begin{array}{c}34.4 \\
(49900\end{array}$ & 2.26 & $\begin{array}{l}2448 \\
(550)\end{array}$ & $\begin{array}{c}32.1 \\
(4660)\end{array}$ & 479 & $\begin{array}{c}34.7 \\
(5028)\end{array}$ & $0.93^{\dagger}$ \\
\hline 8 & S4012.0 & $\begin{array}{c}17.0 \\
(2460)\end{array}$ & $\begin{array}{c}25.9 \\
(3760)\end{array}$ & 1.53 & $\begin{array}{l}1922 \\
(432)\end{array}$ & $\begin{array}{c}24.1 \\
(3490)\end{array}$ & 506 & $\begin{array}{c}37.5 \\
(5433)\end{array}$ & $0.93^{\dagger}$ \\
\hline 9 & S45I1.5 & $\begin{array}{c}19.8 \\
(2870) \\
\end{array}$ & $\begin{array}{c}34.3 \\
(4970) \\
\end{array}$ & 1.73 & $\begin{array}{l}2670 \\
(600) \\
\end{array}$ & $\begin{array}{c}35.5 \\
(5150) \\
\end{array}$ & 546 & $\begin{array}{c}42 \\
(6083) \\
\end{array}$ & $1.04+$ \\
\hline 10 & S37I1.5 & $\begin{array}{c}15.2 \\
(2200)\end{array}$ & $\begin{array}{c}22.6 \\
(3270)\end{array}$ & 1.49 & $\begin{array}{l}2003 \\
(450)\end{array}$ & $\begin{array}{c}25.4 \\
(3680)\end{array}$ & 478 & $\begin{array}{c}34.6 \\
(5011)\end{array}$ & $1.13^{\dagger}$ \\
\hline 11 & S30l1.5 & $\begin{array}{c}13.4 \\
(1940)\end{array}$ & $\begin{array}{c}25.6 \\
(3710)\end{array}$ & 1.91 & $\begin{array}{l}1980 \\
(445)\end{array}$ & $\begin{array}{c}18.2 \\
(3640)\end{array}$ & 489 & $\begin{array}{c}31.6 \\
(4579)\end{array}$ & $0.98^{\dagger}$ \\
\hline \multicolumn{8}{|c|}{$¥$ Specimens 1-11 from Bianchini et al $^{2}$} & \multicolumn{2}{|c|}{$\begin{array}{l}\text { Average }=1.02 \\
\text { Std. } \\
\text { deviation }=0.114\end{array}$} \\
\hline
\end{tabular}




\begin{tabular}{|c|c|c|c|c|c|c|c|c|c|}
\hline 12 & A1-A & 40 & 105 & 2.63 & 3914 & 100.3 & 11.3 & 106 & 0.96 \\
\hline 13 & A1-B & 40 & 105 & 2.63 & 3678 & 93.1 & 9.18 & 94 & 0.99 \\
\hline 14 & A1-C & 40 & 105 & 2.63 & 3498 & 87.6 & 7.06 & 81.5 & 1.07 \\
\hline 15 & A2-A & 46 & 112 & 2.43 & 3820 & 97.4 & 8.55 & 96.3 & 1.01 \\
\hline 16 & A2-B & 46 & 112 & 2.43 & 3807 & 97 & 7.13 & 87.9 & 1.10 \\
\hline 17 & A2-C & 46 & 112 & 2.43 & 3591 & 90.4 & 5.7 & 79.5 & 1.14 \\
\hline 18 & A3-A & 25 & 89 & 3.56 & 3437 & 85.7 & 7.53 & 69.3 & 1.24 \\
\hline 19 & A3-B & 25 & 89 & 3.56 & 3174 & 77.6 & 6.12 & 60.9 & 1.27 \\
\hline 20 & A3-C & 25 & 89 & 3.56 & 2275 & 50.1 & 4.7 & 52.6 & 0.95 \\
\hline 21 & A4-A & 23 & 106 & 4.61 & 3272 & 80.6 & 7.53 & 67.3 & 1.20 \\
\hline 22 & A4-B & 23 & 106 & 4.61 & 2927 & 70.1 & 6.12 & 59 & 1.19 \\
\hline 23 & A4-C & 23 & 106 & 4.61 & 2376 & 53.2 & 4.7 & 50.6 & 1.05 \\
\hline 24 & B-1 & 42 & 104 & 2.48 & 4072 & 71.5 & 6.7 & 81.5 & 0.88 \\
\hline 25 & B-2 & 42 & 104 & 2.48 & 5359 & 96.1 & 8.93 & 94.5 & 1.02 \\
\hline 26 & B-3 & 44 & 113 & 2.57 & 5078 & 90.7 & 6.83 & 84.2 & 1.08 \\
\hline 27 & B-4 & 44 & 113 & 2.57 & 6298 & 114 & 11.36 & 110.8 & 1.03 \\
\hline 28 & B-5 & 15 & 95 & 6.33 & 2703 & 45.4 & 6.15 & 51.2 & 0.89 \\
\hline 29 & B-6 & 15 & 95 & 6.33 & 3720 & 64.8 & 8.32 & 63.9 & 1.01 \\
\hline 30 & B-7 & 19 & 120 & 6.32 & 2758 & 47.5 & 6.08 & 54.7 & 0.87 \\
\hline 31 & B-8 & 19 & 120 & 6.32 & 4032 & 72.3 & 8.22 & 67.35 & 1.07 \\
\hline
\end{tabular}

\begin{tabular}{|c|c|c|c|c|c|c|c|c|c|}
\hline \multicolumn{8}{|c|}{ ‡Specimens $12-31$ from Ospina et $\mathrm{al}^{4}$} & \multicolumn{2}{|c|}{$\begin{array}{l}\text { Average }=1.05 \\
\text { Std } \\
\text { deviation }=0.113\end{array}$} \\
\hline 32 & C & $\begin{array}{c}29.7 \\
(4300)\end{array}$ & $\begin{array}{c}89 \\
(12900)\end{array}$ & 3 & $\begin{array}{l}3787 \\
(850)\end{array}$ & $\begin{array}{c}59.9 \\
(8690)\end{array}$ & $\begin{array}{l}5.61 \\
(813)\end{array}$ & $\begin{array}{c}63.3 \\
(9082)\end{array}$ & 0.95 \\
\hline 33 & D & $\begin{array}{c}30.3 \\
(4400)\end{array}$ & $\begin{array}{c}96.6 \\
(14000)\end{array}$ & 3.18 & $\begin{array}{c}4673 \\
(1050)\end{array}$ & $\begin{array}{c}76.5 \\
(11090)\end{array}$ & $\begin{array}{c}7.86 \\
(1140)\end{array}$ & $\begin{array}{c}76.6 \\
(11100)\end{array}$ & 1.00 \\
\hline 34 & G & $\begin{array}{c}42.8 \\
(6200)\end{array}$ & $\begin{array}{c}90.3 \\
(13100)\end{array}$ & 2.11 & $\begin{array}{c}4895 \\
(11000\end{array}$ & $\begin{array}{c}80.6 \\
(11690)\end{array}$ & $\begin{array}{c}9.31 \\
(1350)\end{array}$ & $\begin{array}{c}96.6 \\
(14100)\end{array}$ & 0.83 \\
\hline 35 & H & $\begin{array}{c}17.2 \\
(2500)\end{array}$ & $\begin{array}{c}85.5 \\
(12400)\end{array}$ & 4.96 & $\begin{array}{l}3338 \\
(750)\end{array}$ & $\begin{array}{c}51.7 \\
(7500)\end{array}$ & $\begin{array}{l}5.93 \\
(860)\end{array}$ & $\begin{array}{c}52 \\
(7540) \\
\end{array}$ & 0.99 \\
\hline 36 & $\mathrm{~K}$ & $\begin{array}{c}35.2 \\
(5100)\end{array}$ & $\begin{array}{c}72.4 \\
(10500)\end{array}$ & 2.06 & $\begin{array}{c}5318 \\
(1195)\end{array}$ & $\begin{array}{c}88.5 \\
(12830)\end{array}$ & $\begin{array}{c}8.48 \\
(1230)\end{array}$ & $\begin{array}{c}83.0 \\
(12030)\end{array}$ & 1.07 \\
\hline 37 & L & $\begin{array}{c}33.1 \\
(4800)\end{array}$ & $\begin{array}{c}83.4 \\
(12100)\end{array}$ & 2.52 & $\begin{array}{l}5118 \\
(1150)\end{array}$ & $\begin{array}{c}84.8 \\
(12290)\end{array}$ & $\begin{array}{c}8.48 \\
(1230)\end{array}$ & $\begin{array}{c}82.8 \\
(12010)\end{array}$ & 1.02 \\
\hline \multicolumn{8}{|c|}{ ¥Specimens $32-37$ from Gamble et al $^{3}$} & \multicolumn{2}{|c|}{$\begin{array}{l}\text { Average }=0.97 \\
\text { Std. } \\
\text { deviation }=0.066\end{array}$} \\
\hline \multicolumn{10}{|c|}{$\begin{array}{l}\text { Overall Average }=1.03 \\
\text { Std. } \text { deviation }=0.111\end{array}$} \\
\hline & & & & & & & & & \\
\hline
\end{tabular}




\section{EXPERIMENTAL RESULTS AND DISCUSSION}

\section{Compressive Strength and Confinement Reinforcement}

Compressive strength of the floor slab is governed by the confinement stress which is dependent on the slab reinforcement. It appears that both top and bottom slab reinforcements are equally effective in providing confinement to the column force within the slab. If the slab reinforcement is stressed initially due to loading applied to the slab its effectiveness in providing confinement is reduced but account has to be taken of the compression force generated from the bending moment in the slab caused by the slab loading. Consideration has also to be given to the anchorage length of the slab reinforcement as full yield strength cannot be achieved if this is inadequate.

\section{Crack Pattern}

Bianchini's specimens ${ }^{2}$ show crack patterns different from that for Ospina' ${ }^{3}$ and Gamble's specimens ${ }^{3}$. Diagonal cracks were observed in the latter. A possible reason is that cracks tend to form at right angles to slab reinforcement. For Bianchini's specimens there were no steel reinforcement between locations $j$ and $f$ (see Fig. 4) whereas for Ospina and Gamble's specimens there were reinforcement in two directions between corresponding locations $m$ and $n$ (see Fig. 5). Hence in the latter the diagonal cracks formed at $45^{\circ}$ to the slab reinforcement running in two perpendicular directions.

\section{Further Research}

Further research needs to be done for cases where confinement from slab for edge and corner columns and also where confinement is provided by beams. Where beams are concerned consideration needs to be taken of the width of the beam as this could be less than the column width 1 . There is also a need to study further the effect of the depth of slab to column width ratio on column strength. Specimens considered in this paper have depth of slab to column width ratio of $0.5-1.17$. But as slab thickness increase relative to column width the confining effect of slab reinforcement may be reduced.

\section{CONCLUSIONS}

A method has been proposed to predict the compressive strength of a column/slab joint based on confining pressure derived from the slab reinforcement. This method would enable one to predict the location of failure ie. whether failure is in the column or in the slab. Comparison of predicted to actual failure stresses shows good agreement. But more work needs to be done to take into consideration confinement from beams and also from slabs for edge and corner columns.

\section{REFERENCES}

1. Siao, W.B., "Reinforced Concrete Column Strength at Beam/ Slab and Column Intersection", ACI Structural Journal, V. 91, No. 1, Jan.-Feb. 1994, pp. 3-8.

2. Bianchini, A.C.; Woods, R.E.; and Kesler, C.E., "Effect of Floor Concrete Strength on Column Strength", ACI Structural Journal, V. 56, No. 11, May 1960, pp. 1149-1169.

3. Ospina, C.E.; and Alexander, Scott D.B. and Kesler, C.E., "Transmission of Interior Concrete Column Loads Through Floors", J. Struct. Engrg., ASCE,1998, 124(6), pp.602-610.

4. Gamble,W.L.; and Klinar,J.D., "Tests of high strength concrete columns with intervening floor slabs", J.Struct.Engrg., ASCE, 1991, 117(5), pp.1462-1476.

5. ACI Committee 318, "Building Code Requirements for Structural Concrete (ACI318-05)”, ACI, Detroit, Mich.

\section{PROFILES}

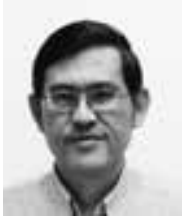

IR. SIAO WEN BIN is a senior lecturer with the Faculty of Engineering, Utar, Sungai Long Campus. His research interests are deep beams, flat slabs and beam openings in reinforced/prestressed concrete beams. 


\section{APPENDIX}

\section{SAMPLE CALCULATIONS}

\section{Specimen S90I3.0 ${ }^{2}$ (Figures 1 \& 4)}

Slab reinforcement 4 nos. $1 / 2$ in $(12.7 \mathrm{~mm})$ diameter bars top and 4 nos. $1 / 2$ in. diameter bars bottom; $\mathrm{f}_{\mathrm{y}}=45 \mathrm{ksi} .\left(31 \mathrm{Nmm}^{-2}\right) ; f_{c}^{\prime}=2480 \mathrm{psi} .\left(17.1 \mathrm{Nmm}^{-2}\right)$

Slab dimensions : 31 "x31"x7"thick(787mmx787mmx178mm)

Column size $=11$ in. sq. $(279 \mathrm{~mm}) ;$ Reinforcement $=4$ nos. $3 / 4$ in $(19 \mathrm{~mm})$ diameter; $\mathrm{f}_{\mathrm{y}}=46.87 \mathrm{ksi} .\left(323 \mathrm{Nmm}^{-2}\right)$; $f_{c}^{\prime}=7400 \mathrm{psi}\left(51 \mathrm{Nmm}^{-2}\right)$

Eqn (3)

$$
\begin{aligned}
& l_{d}=\frac{f_{y}}{25 \sqrt{f_{c}^{\prime}}} d_{b} \\
& l_{d}=\frac{45000}{25 \sqrt{2480}} \times \frac{1}{2}=18.1 "(457 \mathrm{~mm})
\end{aligned}
$$

Force in slab bars -4 nos. \# 4 bars top and bottom $\mathrm{F}=\frac{8 \pi x 0.5^{2} x 45}{4}=70.7$ kips $(315 \mathrm{kN})$

Anchorage length provided $=\frac{31-11}{2}=10^{\prime \prime}(254 \mathrm{~mm})$

Hence confining force $=\frac{10 \times 70.7}{18.1}=39.1$ kips $(174 \mathrm{kN}) \rightarrow f_{1}=\frac{39100}{7 \times 11}=508$ si..$\left(3.5 \mathrm{Nmm}^{-2}\right)$

$\operatorname{Eqn}(1)$

$$
\begin{aligned}
& 0.85 f_{c p}^{\prime}=0.85 f_{c s}^{\prime}+\mathrm{k}_{1} \mathrm{f}_{1} \\
& 0.85 f_{c p}^{\prime}=0.85 \times 2480+5 \times 508 \\
& f_{c p}^{\prime}=5470 p s i\left(37.7 \mathrm{Nmm}^{-2}\right)
\end{aligned}
$$

$\operatorname{Eqn}(2)$

$$
\begin{gathered}
\mathrm{P}_{\mathrm{u}}=\mathrm{A}_{5} \mathrm{f}_{\mathrm{y}}+\mathrm{A}_{\mathrm{n}} 0.85 f_{c e}^{\prime} \\
700=\frac{4 \pi x 0.75^{2} \times 46.87}{4}+\left(11^{2}-\frac{4 \pi x 0.75^{2}}{4}\right) 0.85 f_{c e}^{\prime} \\
f_{c e}^{\prime}=6090 \mathrm{psi}\left(42 \mathrm{Nmm}^{-2}\right)\{6110 \mathrm{psi} \text { as computed by Biachini }\} \\
\frac{f_{c e}^{\prime}}{f_{c p}}=\frac{6110}{5470}=1.12
\end{gathered}
$$




\section{Specimen Al-A ${ }^{3}$ (Figures 8 \& 9)}

Slab reinforcement 4 nos. $3 / 8$ in ( $9.5 \mathrm{~mm})$ diameter bars top and 2 nos. $3 / 8$ in diameter bars bottom; $\mathrm{f}_{\mathrm{b}}=400 \mathrm{Nmm}^{-2}$. (58ksi); $f_{c}^{\prime}=40 \mathrm{Nmm}^{-2}(5800 \mathrm{psi})$

Slab dimensions : $1380 \mathrm{mmx} 1380 \mathrm{mmx} 100 \mathrm{~mm}$ thick $\left(54^{\prime \prime} \times 54^{\prime \prime} \times 4^{\prime \prime}\right)$

Column size $=200 \mathrm{~mm}$. sq. $\left(8^{\prime \prime}\right) ;$ Reinforcement $=6$ nos. $15 \mathrm{~mm}\left(0.6^{\prime \prime}\right)$ diameter; $\mathrm{f}_{\mathrm{y}}=400 \mathrm{Nmm}^{-2}(58 \mathrm{ksi}) ; f_{c}^{\prime}=105$ $\mathrm{Nmm}^{-2}(15225 \mathrm{psi})$

Eqn (3)

$$
\begin{aligned}
& l_{d}=\frac{f_{y}}{25 \sqrt{f_{c}^{\prime}}} d_{b} \\
& l_{d}=\frac{400 \times 145}{25 \sqrt{2480 \times 145}} \times \frac{3}{8} \times 25.4=291 \mathrm{~mm}\left(11.5^{\prime \prime}\right)
\end{aligned}
$$

Anchorage length for bar ' $b$ ' is $\frac{1380-200}{2 \times 2}=295\left(11.6^{\prime \prime}\right)>291 \mathrm{~mm}$.

Hence consider bars ' $b$ ', $c$ ' \&' $d$ ' as capable of achieving full yield strength. Ignore bar ' $a$ '.

Force in slab bars -6 nos. \# 3 bars top and 2 nos. \# 3 bars bottom

Hence confining force $\mathrm{F}=\frac{\mathrm{B} \pi x 0.375^{2} \times 25.4^{2} \times 400}{4}=227.9 \mathrm{kN}(5 \mathrm{lkips})$

Confining stress $f_{1}=\frac{227.9 \times 1000}{200 \times 100}=11.4 \mathrm{Nmm}^{-2}(1653 \mathrm{psi})$

$\operatorname{Eqn}(1)$

$$
\begin{aligned}
& 0.85 f_{c p}^{\prime}=0.85 f_{c s}^{\prime}+\mathrm{k}_{1} \mathrm{f}_{\mathrm{l}} \\
& 0.85 f_{c p}^{\prime}=0.85 \times 40+5 \times 11.4 \\
& f_{c p}^{\prime}=107 \mathrm{Nmm}^{-2}(15515 \mathrm{psi})>f_{c c}^{\prime}=105 \mathrm{~N} / \mathrm{mm}^{-2} \rightarrow \text { column failure }
\end{aligned}
$$

$\operatorname{Eqn}(2)$

$$
P_{u}=A_{s} f_{y}+A_{n} 0.85 f_{c e}^{\prime}
$$

$$
\begin{aligned}
& 3914 \times 1000=\frac{8 \pi x 15^{2} x 400}{4}+\left(200^{2}-\frac{8 \pi x 15^{2}}{4}\right) 0.85 f_{c e}^{\prime} \\
& f_{c e}^{\prime}=102.1(14790 \mathrm{psi})\{100.3(14545 \mathrm{psi}) \text { as calculated by Ospina }\} \\
& \frac{f_{c e}^{\prime}}{f_{c p}}=\frac{100.3}{105}=0.96
\end{aligned}
$$




\section{Specimen A1-B ${ }^{3}$ (Figures 8 \& 9)}

Specimen Al-B is similar to Al-A except that the slab was subjected to vertical point loads so that bars were stressed to reach half yield strain due to bending moment induced in the slab by the point loads.

Force in slab bars - consider 6 nos. \# 3 bars top and 2 nos. \# 3 bars bottom as in Al -A.

However since top bars were at $50 \%$ yield due to bending they are considered to be only $50 \%$ effective where contribution to confining pressure is concerned. But bottom bars should be fully effective.

Thus restraining force from top and bottom bars combined are

$$
\frac{(0.5 x 6+2) \pi x 0.37 s^{2} \times 25.4^{2} x 400}{4}=142 \mathrm{kN}(31.9 \mathrm{kips})
$$

Due to bending tension is induced in top bars with corresponding compression in bottom of slab. Consider half of this force to be effective in restraining column (Figure 11):

Thus restraining force from compression in bottom of slab :

$$
\frac{(0.5 \times 6) \pi \times 0.375^{2} \times 25.4^{2} \times 400}{4} \times 0.5=42.7 \mathrm{kN}(9.6 \mathrm{kips})
$$

Hence total confining force $\mathrm{F}=142+42.7=185 \mathrm{kN}(41.6 \mathrm{kips})$

Confining stress $f_{1} \frac{185 \times 1000}{200 \times 100}=9.25 \mathrm{Nmm}^{-2}(134 \mathrm{lpsi})$

Eqn(1)

$$
\begin{aligned}
& 0.85 f_{c p}^{\prime}=0.85 f_{c s}^{\prime}+\mathrm{k}_{1} \mathrm{f}_{1} \\
& 0.85 f_{c p}^{\prime}=0.85 \times 40+5 \times 9.25 \\
& f_{c p}^{\prime}=94 \mathrm{Nmm}^{-2}(13630 \mathrm{psi})
\end{aligned}
$$

$\operatorname{Eqn}(2)$

$$
\begin{aligned}
& \mathrm{P}_{\mathrm{u}}=\mathrm{A}_{\mathrm{f}_{\mathrm{y}}}+\mathrm{A}_{\mathrm{n}} 0.85 f_{c e}^{\prime} \\
& 3678 \times 1000=\frac{8 \pi \times 15^{2} \times 4 \mathrm{nj}}{4}+\left(200^{2}-\frac{8 \pi \times 15^{2}}{4}\right) 0.85 f_{c e}^{\prime} \\
& f_{c e}^{\prime}=94.9\left(93.08 \text { as calculated by Ospina }{ }^{3}\right)(13616 \mathrm{ps} \\
& \frac{f_{c e}^{\prime}}{f_{c p}^{\prime}}=\frac{93.0 \mathrm{~B}}{94}=0.99
\end{aligned}
$$




\section{Specimen $C^{4}$ (Figures 10 \& 11)}

Slab reinforcement 10 nos. $1 / 2$ in $(12.7 \mathrm{~mm})$ diameter bars top;

$\mathrm{f}_{\mathrm{y}}=72.5 \mathrm{ksi}\left(500 \mathrm{Nmm}^{-2}\right) ; f_{\mathrm{c}}^{\prime}=4.3 \mathrm{ksi} .\left(29.7 \mathrm{Nmm}^{-2}\right)$

Slab dimensions : 42 " $\mathrm{x} 42$ " $\mathrm{x} 7$ "thick(1070 $\mathrm{mmx} 1070 \mathrm{mmx} 175 \mathrm{~mm}$ )

Column size $=10^{\prime \prime} \mathrm{sq} .(254 \mathrm{~mm}) ;$ Reinforcement $=4$ nos.\#6 $(19 \mathrm{~mm})$ bars; $\mathrm{f}_{\mathrm{y}}=70.5 \mathrm{ksi} .\left(486 \mathrm{Nmm}^{-2}\right)$;

$f_{c}^{\prime}=12.9 \mathrm{ksi}\left(89 \mathrm{Nmm}^{-2}\right)$

Eqn (3)

$$
\begin{aligned}
& l_{d}=\frac{f_{y}}{25 \sqrt{f_{f}^{\prime}}} d_{b} \\
& l_{d}=\frac{72500}{25 \sqrt{4300}} \times \frac{1}{2}=22^{\prime \prime}(559 \mathrm{~mm})
\end{aligned}
$$

Anchorage length for bar ' $e$ ' is $\frac{42-10}{2}=16<22$ " $\rightarrow$ all bars not able to achieve yield strength.

Ignoring bar ' $a$ ' total anchorage lengths of bars ' $b$ ', $c$ ', $d$ ' and ' $e$ ' $=2(6+10+14+16)-4=88$ " $(2235 \mathrm{~mm})$ (assume cover $=1 / 2^{\prime \prime}$ )

Hence equivalent number of bars $=\frac{88}{22}=4$ nos.

Hence confining force $\mathrm{F}=\frac{4 \pi \times 0.5^{2} \times 72.5}{4}=56.9 \mathrm{kips}$. $(253 \mathrm{kN})$

Confining stress $f_{t} \frac{56.9 \times 1000}{7 \times 10}=813 \mathrm{psi}\left(5.61 \mathrm{Nmm}^{-2}\right)$

$\operatorname{Eqn}(1)$

$$
\begin{aligned}
& 0.85 f_{c p}^{\prime}=0.85 f_{c s}^{\prime}+\mathrm{k}_{1} \mathrm{f}_{\mathrm{l}} \\
& 0.85 f_{c p}^{\prime}=0.85 \times 4300+5 \times 813 \\
& f_{c p}^{\prime}=9082 \text { psi. }\left(62.6 \mathrm{Nmm}^{-2}\right)
\end{aligned}
$$

$\operatorname{Eqn}(2)$

$$
\begin{aligned}
& \mathrm{P}_{\mathrm{u}}=\mathrm{A}_{3} \mathrm{f}_{\mathrm{y}}+\mathrm{A}_{\mathrm{n}} 0.85 f_{c e}^{\prime} \\
& 850 \times 1000=\frac{4 \pi \times 0.75^{2} \times 70.5}{4}+\left(10^{2}-\frac{4 \pi \times 0.75^{2}}{4}\right) 0.85 f_{c e}^{\prime} \\
& f_{c e}^{\prime}=8689 \mathrm{psi} .\left(8690 \text { as calculated by Gamble }{ }^{4}\right)\left(59.9 \mathrm{Nmm}^{-2}\right) \\
& \frac{f_{c e}^{\prime}}{f_{c p}^{\prime}}=\frac{8690}{9082}=0.96
\end{aligned}
$$

